\title{
Heavy Metals Contamination in Soils and Water in the Vicinity of Small Scale Gold Mines at Londoni and Sambaru, Singida Region, Tanzania
}

\author{
Asantael Herman ${ }^{1}$, Charles Kihampa ${ }^{2}$ \\ ${ }^{1}$ Department of Environmental Engineering and Management, University of Dodoma, Dodoma, Tanzania \\ ${ }^{2}$ Department of Environmental Science and Management, Ardhi University, Dar es Salaam, Tanzania
}

Email address:

ahmlay@gmail.com (A. Herman), kihampa@yahoo.com (C. Kihampa)

\section{To cite this article:}

Asantael Herman, Charles Kihampa. Heavy Metals Contamination in Soils and Water in the Vicinity of Small Scale Gold Mines at Londoni and Sambaru, Singida Region, Tanzania. International Journal of Environmental Monitoring and Analysis. Vol. 3, No. 6, 2015 , pp. $397-403$. doi: $10.11648 /$ j.ijema.20150306.13

\begin{abstract}
This study was carried out to determine the concentration of heavy metals in water and soils in the vicinity of mines and processing units in small scale mining areas at Londoni and Sambaru. Heavy metals concentrations ranging from 1.7 to 53.8 $\mathrm{mg} / \mathrm{kg}$ dry soil weight (dw), 8.7 to $22.24 \mathrm{mg} / \mathrm{kg} \mathrm{dw}, 0.42$ to $2.61 \mathrm{mg} / \mathrm{kg} \mathrm{dw}$ and 3.19 to $29.42 \mathrm{mg} / \mathrm{kg} \mathrm{dw}$ were detected for $\mathrm{Hg}, \mathrm{Pb}$, $\mathrm{Zn}$ and $\mathrm{Cu}$, respectively. Concentration of the same metals detected in surface and groundwater samples ranged from 0.013 to $0.17 \mathrm{mg} / \mathrm{L}$. Concentrations of mercury detected in soil samples were above Tanzanian maximum limits of mercury contamination. Sources of the metals contaminations were envisaged to be amalgamation and burning activities, improper waste rocks and tailings disposal, discharge of mine water to the surroundings and leachates from waste rocks and tailings. The study concluded that immediate adverse effect may not be feasible but continuing contamination may lead to serious human health and environmental problems.
\end{abstract}

Keywords: Heavy Metal, Soils, Water, Small Scale, Vicinity, Londoni, Sambaru

\section{Introduction}

Mining sector plays an important role in economy and development of many countries. Significant contribution is on the employment creation and foreign currency earnings that are essential for socio-economic development [1]. Extraction and purification of mines involves a number of stages or activities, each of which has potentially-adverse impacts on the natural environment, society and cultural heritage, health and safety of mine workers, and communities living in close proximity to operations [2]. In practice, mining activities are categorized in large, medium and small scale based on capital investment, labour and technology requirements.

Focus in the mining sector should not be only on the economic aspects, but on sustainable environmental management, which is part of the integrated global efforts for environmentally friendly production processes [3]. Environmental impacts are common in each mine regardless of the scale of mine but differ from mine to mine depending on different factors including type of minerals and technology used in mining and processing the minerals of interest. The adverse environmental impacts for small scale mining are in general higher than those of other types of mining [4]. This means, the small scale mining is dirtier per unit of output than medium-sized or large and modern mining operations.

Various cases of negative environmental impacts have been reported to occur in small scale mines due to tailings rich of mercury, sewage, industrial wastes, lubricants and other toxic chemicals entering into rivers and soils through runoff and percolation as a result of lack of proper control systems and disposal [5], [6].

Mining involves production of large quantities of waste, especially from gold mines, which account for more than $99 \%$ of ore extracted as waste [7]. Disposal of large quantities of waste during gold extraction, especially in small scale mines characterized by inadequate disposal technology is a challenging issue and may significantly impact on the 
environment.

In Tanzania several studies in mining areas have revealed that environmental problems such as land degradation and pollution are associated with mining activities. For instance it was revealed that, burning of amalgam in open fire has been conducted at Rwamagaza area in Geita and Blue Reef mines at Nyakagwe and Nyamtondo [8]. High concentrations of heavy metals including $\mathrm{Pb}, \mathrm{Cu}, \mathrm{Cd}, \mathrm{Zn}$ and $\mathrm{As}$ have been reported in water and sediments close to North Mara Gold Mine and Mgusu gold processing areas due to surface runoff [9], [10].

The mining industry has an obligation to prevent release of toxic metals into the environment thereby ensuring that humans, birds, animals, and aquatic life are not endangered by the storage and discharge of wastewaters [11]. The results presented in this study therefore form part of the worldwide effort to control the environment against anthropogenic pollution. The objective was to ascertain heavy metal pollutants levels in the selected small scale mining areas. These baseline data are important in designing the management and conservation programmes in the small scale mining areas in Tanzania.

\section{Materials and Methods}

\subsection{Study Area Description}

The study was conducted at small scale mining areas demarcated at Londoni and Sambaru villages in Singida region, Tanzania. The area lies between latitudes $05^{\circ} 15^{\prime} 00^{\prime \prime} \mathrm{S}$ to $05^{\circ} 30$ ' $00^{\prime \prime} \mathrm{S}$ and longitudes $3^{\circ} 500^{\prime} 00^{\prime \prime} \mathrm{E}$ to $35^{\circ} 15^{\prime} 00^{\prime \prime} \mathrm{E}$.Itis hilly, covered with reddish iron rich soils, thorn bushes, grasses and small trees. The mining operations at the study area involve digging holes, crushing and grinding of ore, washing and trapping of gold minerals using sluice tables, amalgamation and burning activities and finally gold recovery in tailings using cyanide solution in leaching tanks.

Fig. 1 shows land cover and various human activities within the area.

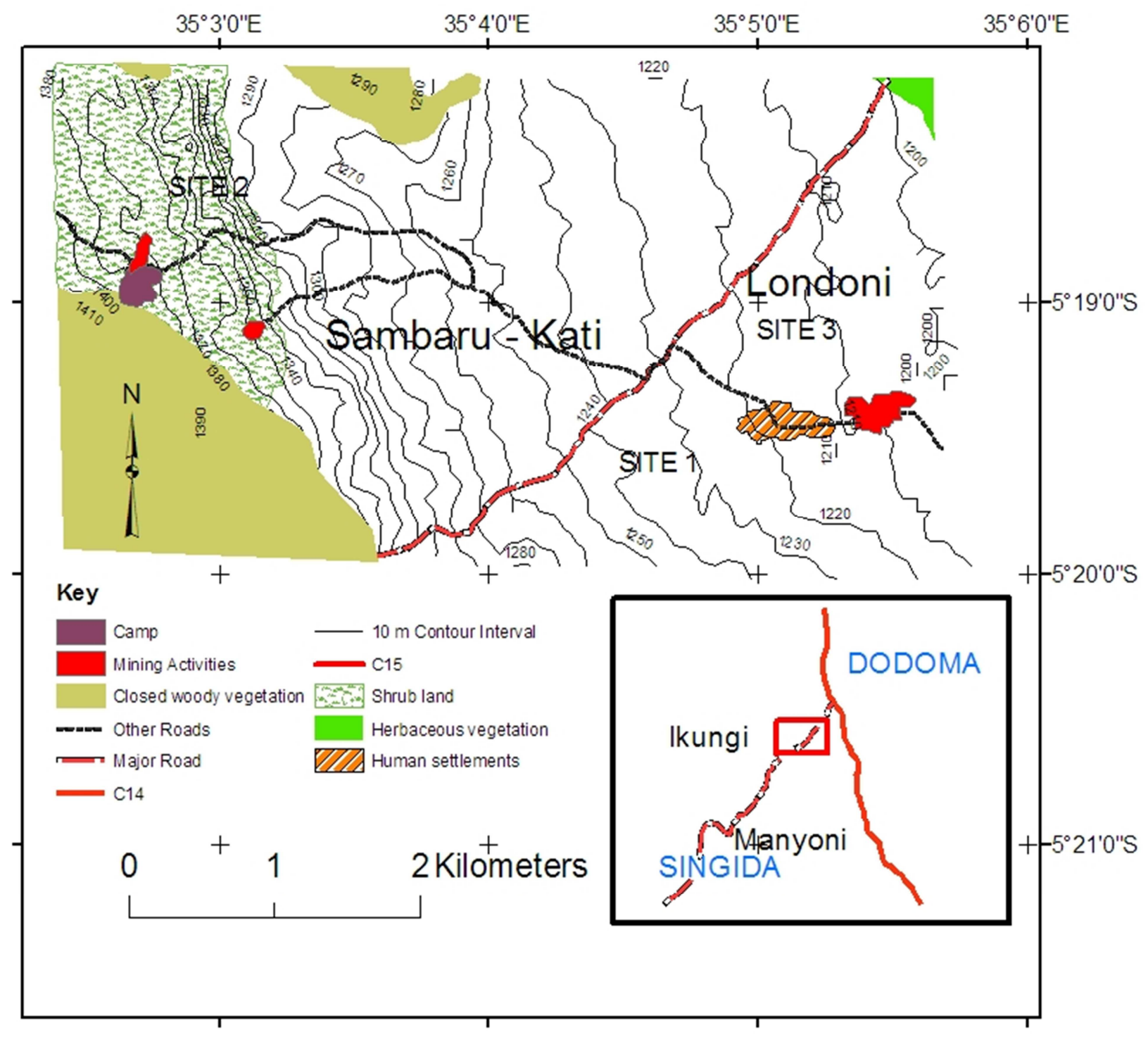

Figure 1. Land cover and different human activities around the mining sites in Londoni and Sambaru. 


\subsection{Sample Collection}

Water and soil samples were collected from mines and processing units in March and June 2013. The sampling sites are described in Table 1 and indicated in the map in Fig. 2. The indication of sampling sites in the area was enables by Global Position System (GPS) points that were measured during sampling campaigns.

Water samples were collected by grabbing technique and placed in $1000 \mathrm{~mL}$ plastic bottles. The samples were collected from community bore holes and dug well, mine shafts drainage, abandoned shaft and stagnant water in the vicinity of amalgamation processing units (Table 1). Before collection, the sampling bottles which were previously soaked overnight with $10 \% \mathrm{HCl}$ and rinsed with distilled water were rinsed with water to be sampled [12]. After sampling, the samples were measured for temperature, $\mathrm{pH}$, and EC using a hand-held water quality portable monitor. Three measurements were made for each parameter at each sampling location $(n=3)$ during sampling expeditions, and mean values were calculated The instrument was calibrated at the beginning of every sampling day. The collected water samples were then filtered, preserved with concentrated $\mathrm{HNO}_{3}$, stored in cold boxes and transported to the Laboratory of the School of Environmental Science and Technology (SEST), Ardhi University, where they were immediately analyzed upon.

Soil samples were collected from thirteen established sites (S1-S13) at depths of 0 to $15 \mathrm{~cm}$ and 15 to $30 \mathrm{~cm}$ (Table 1). Twenty six measurements were made for each parameter at each sampling location $(n=2)$ during sampling expeditions, and mean values were calculated. To ensure uniform volume of soil is taken through the full depth of each sampling increment, the samples were collected by using probe and auger design as described in literature [13]. The collected soil samples each of $0.5 \mathrm{~kg}$ were stored in polyethylene bags, placed in cool boxes and transported to SEST laboratory for extraction and analysis.

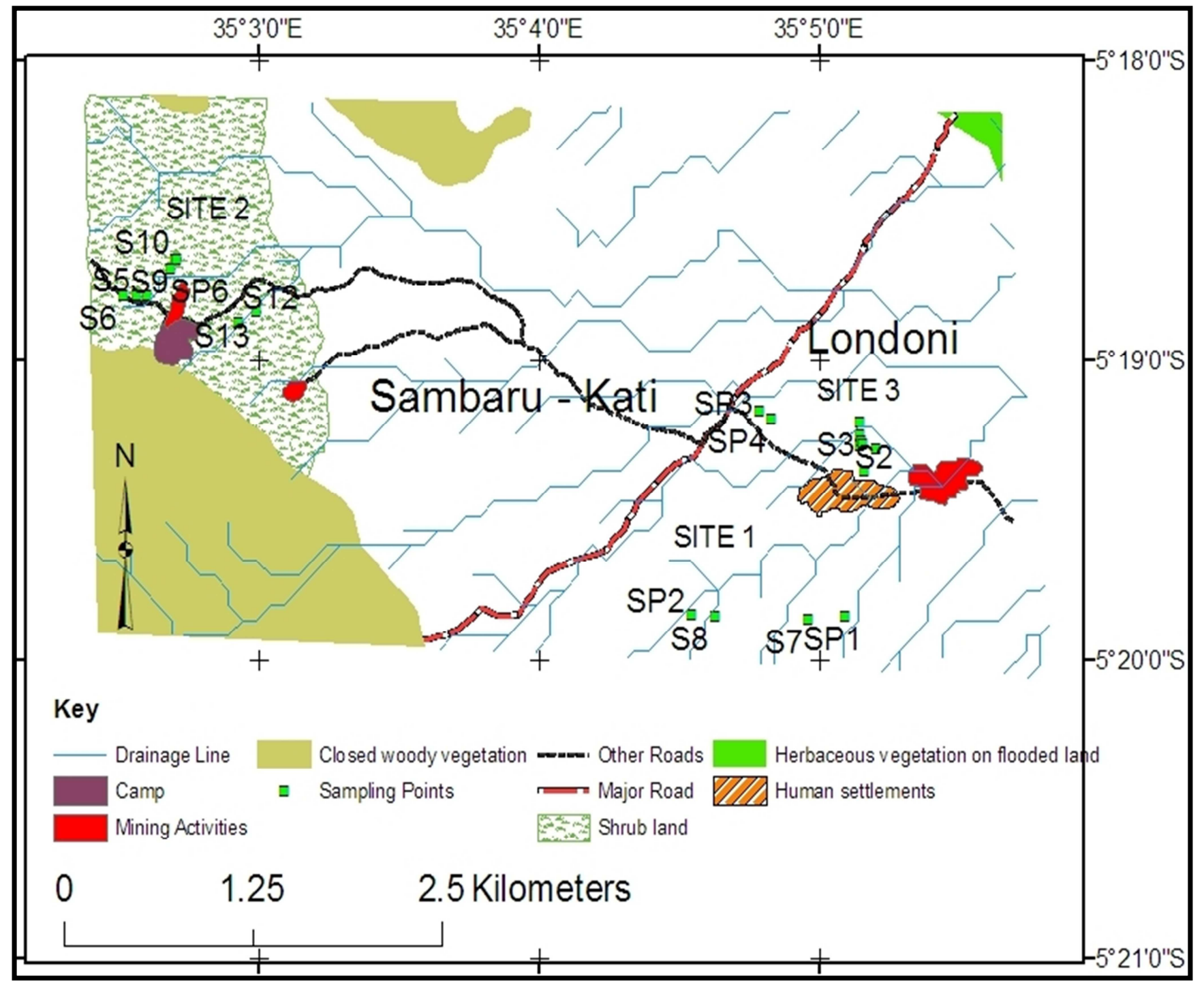

Figure 2. Map showing sampling points in the vicinity of mines and processing units. 
Table 1. Description of sampling sites for soil and water samples.

\begin{tabular}{|c|c|c|}
\hline Site & Coordinates & Sample/site characteristics \\
\hline S1 & $\begin{array}{l}731149 \mathrm{E} \\
9411182 \mathrm{~N}\end{array}$ & $\begin{array}{l}\text { Soil sample, collected } 20 \mathrm{~m} \text { from Processing unit at } \\
\text { Londoni centre }\end{array}$ \\
\hline S2 & $\begin{array}{l}731150 \mathrm{E} \\
9411252 \mathrm{~N}\end{array}$ & $\begin{array}{l}\text { Soil sample, collected } 100 \mathrm{~m} \text { from processing unit } \\
\text { at Londoni centre }\end{array}$ \\
\hline S3 & $\begin{array}{l}731154 \mathrm{E} \\
9411332 \mathrm{~N}\end{array}$ & $\begin{array}{l}\text { Soil sample, } 200 \mathrm{~m} \text { from processing unit at Londoni } \\
\text { centre }\end{array}$ \\
\hline S4 & $\begin{array}{l}726446 \mathrm{E} \\
9412123 \mathrm{~N}\end{array}$ & $\begin{array}{l}\text { Soil sample, collected } 20 \mathrm{~m} \text { from processing unit at } \\
\text { Sambaru mine }\end{array}$ \\
\hline S5 & $\begin{array}{l}726374 \mathrm{E} \\
9412125 \mathrm{~N}\end{array}$ & $\begin{array}{l}\text { Soil sample, collected } 100 \mathrm{~m} \text { from processing unit } \\
\text { at Sambaru }\end{array}$ \\
\hline S6 & $\begin{array}{l}726286 \mathrm{E} \\
9412126 \mathrm{~N}\end{array}$ & $\begin{array}{l}\text { Soil sample, collected } 200 \mathrm{~m} \text { from processing unit } \\
\text { at Sambaru mine }\end{array}$ \\
\hline S7 & $\begin{array}{l}731064 \mathrm{E} \\
9410126 \mathrm{~N}\end{array}$ & $\begin{array}{l}\text { Soil sample, collected at the mine shaft at Londoni } \\
\text { small scale mine }\end{array}$ \\
\hline S8 & $\begin{array}{l}730189 \mathrm{E} \\
9410136 \mathrm{~N}\end{array}$ & $\begin{array}{l}\text { Soil sample, collected at waste dump at Londoni } \\
\text { small scale mine }\end{array}$ \\
\hline S9 & $\begin{array}{l}726632 \mathrm{E} \\
9412346 \mathrm{~N}\end{array}$ & $\begin{array}{l}\text { Soil sample, collected at mine shaft at Sambaru } \\
\text { small scale mine }\end{array}$ \\
\hline S10 & $\begin{array}{l}726637 \mathrm{E} \\
9412349 \mathrm{~N}\end{array}$ & $\begin{array}{l}\text { Soil sample, collected at waste dump at Sambaru } \\
\text { small scale mine }\end{array}$ \\
\hline S11 & $\begin{array}{l}731175 \mathrm{E} \\
9411029 \mathrm{~N}\end{array}$ & $\begin{array}{l}\text { Soil sample, collected } 2 \mathrm{~km} \text { from processing unit at } \\
\text { Londoni centre }\end{array}$ \\
\hline $\mathrm{S} 12$ & $\begin{array}{l}727044 \mathrm{E} \\
9412003 \mathrm{~N}\end{array}$ & $\begin{array}{l}\text { Sediments sample, collected } 300 \mathrm{~m} \text { downstream the } \\
\text { processing unit at Sambaru mine }\end{array}$ \\
\hline $\mathrm{S} 13$ & $\begin{array}{l}727162 \mathrm{E} \\
9412020 \mathrm{~N}\end{array}$ & $\begin{array}{l}\text { Sediments sample, collected 500m downstream } \\
\text { processing unit at Sambaru Mine }\end{array}$ \\
\hline S14 & $\begin{array}{l}731156 \mathrm{E} \\
9411208 \mathrm{~N}\end{array}$ & $\begin{array}{l}\text { Tailings sample, collected from active tailings at } \\
\text { Londoni processing centre }\end{array}$ \\
\hline S15 & $\begin{array}{l}731167 \mathrm{E} \\
9411194 \mathrm{~N}\end{array}$ & $\begin{array}{l}\text { Tailings sample, collected from exhausted tailings } \\
\text { at Londoni processing centre }\end{array}$ \\
\hline SP1 & $\begin{array}{l}731063 \mathrm{E} \\
9410125 \mathrm{~N}\end{array}$ & $\begin{array}{l}\text { Mine drainage sample, collected at Londoni small } \\
\text { scale mine }\end{array}$ \\
\hline SP2 & $\begin{array}{l}730035 \mathrm{E} \\
9410149 \mathrm{~N}\end{array}$ & $\begin{array}{l}\text { Shaft water sample, collected at the abandoned } \\
\text { shaft at Londoni small scale mine }\end{array}$ \\
\hline SP3 & $\begin{array}{l}730487 \mathrm{E} \\
9411400 \mathrm{~N}\end{array}$ & $\begin{array}{l}\text { Water sample, collected from community bore hole } \\
\text { at Londoni village }\end{array}$ \\
\hline SP4 & $\begin{array}{l}730569 \mathrm{E} \\
9411353 \mathrm{~N}\end{array}$ & $\begin{array}{l}\text { Water sample, collected from community dug well } \\
\text { at Londoni village }\end{array}$ \\
\hline SP5 & $\begin{array}{l}731262 \mathrm{E} \\
9411168 \mathrm{~N}\end{array}$ & $\begin{array}{l}\text { Storm water sample, collected at Londoni } \\
\text { processing centre }\end{array}$ \\
\hline SP6 & $\begin{array}{l}726601 \mathrm{E} \\
9412288 \mathrm{~N}\end{array}$ & $\begin{array}{l}\text { Storm water sample, collected at Sambaru small } \\
\text { scale mine }\end{array}$ \\
\hline
\end{tabular}

\subsection{Heavy Metal Determination}

Heavy metals determination was carried out by Perkin Elmer Analyst 100 AAS with Perkin Elmer HGA 850 Graphite Furnace and Perkin Elmer AS 800 Auto-sampler made in Germany [12]. For analytical quality assurance, after every five sample readings, standards were run to make sure that the margin of error is within 5\%. In every analytical batch, $10 \%$ samples of all were analyzed repeatedly to ensure the precision and accuracy of analysis. Standard reagents and blanks were also used in the process of analysis to ensure the precision. A $10 \mathrm{~cm}$ long slot-burner head, a lamp and a standard air-acetylene flame were used. The detection limit was $0.01 \mathrm{ppm}(0.01 \mathrm{mg} / \mathrm{kg})$, slit width $0.70 \mathrm{~nm}$ and elements wavelength were 253.7, 283.3, 213.9 and $324.8 \mathrm{~nm}$ for $\mathrm{Hg}, \mathrm{Pb}$, $\mathrm{Zn}$ and $\mathrm{Cu}$, respectively [12]. Water samples, previous filtered and preserved with $\mathrm{HNO}_{3}$ were analyzed directly into AAS, without any further treatment. The soil samples were oven dried at $105^{\circ} \mathrm{C}$ for $24 \mathrm{~h}$, followed by grinding and sieving using $1 \mathrm{~mm}$ sieve. $0.5 \mathrm{~g}$ of dry soil sample was poured into a graduated test tube and mixed with $2 \mathrm{ml}$ of aqua regia 1:3 (1 conc. $\mathrm{HCl}: 3$ conc. $\mathrm{HNO}_{3}$ ). The mixture was digested on a hot plate at $95^{\circ} \mathrm{C}$ for $1 \mathrm{~h}$ and allowed to cool to room temperature [14]. The sample was then diluted to $10 \mathrm{ml}$ using distilled water and left to settle overnight. The supernatant was filtered and analyzed into AAS.

\section{Results and Discussion}

\subsection{Heavy Metals Concentrations in Soils}

Concentrations of heavy metals at the vicinity of mines and processing unit are presented in Table 2. Maximum concentrations of lead, zinc and copper were $22.24 \pm 0.069$, $2.61 \pm 0.13$ and $29.42 \pm 6.145 \mathrm{mg} / \mathrm{kg} \mathrm{dw}$, respectively at a depth of $0-15 \mathrm{~cm}$ from the soil surface. Points with maximum concentrations were S8 for lead and zinc, and S9 for copper. High concentrations of heavy metals at S8 and S9 points might be due to the precipitation of heavy metals from rock dumps deposited adjacent to mine shaft as well as discharging of mine drainage from mine shaft to the surroundings. Fig. 3 shows variations of heavy metals concentrations in various sampling sites. Despite of high concentrations of lead, zinc and copper in the area still their concentrations were within the maximum allowable limits as per Tanzania Standard for habitat and agricultural of $200 \mathrm{mg} / \mathrm{kg}$ for lead, $200 \mathrm{mg} / \mathrm{kg}$ for copper and $150 \mathrm{mg} / \mathrm{kg}$ for zinc. The concentrations for $\mathrm{Pb}$ and $\mathrm{Zn}$ in soils were also within the European Mediterranean Region maximum standards of $22.8 \pm 16.1 \mathrm{mg} / \mathrm{kg}$ for $\mathrm{Pb}$ and $52.8 \pm 149.9 \mathrm{mg} / \mathrm{kg}$ for $\mathrm{Zn}$, while that of $\mathrm{Cu}$ in Londoni and Sambaru sites were above the maximum allowable limits of $22.5 \pm 8.9 \mathrm{mg} / \mathrm{kg}$ [15], [16], [17].

Although $\mathrm{Pb}$ and $\mathrm{Zn}$ levels were below maximum allowable concentrations, continuing kettle keeping around mining areas and cultivating near the amalgamation units in Londoni amalgamation centre can eventually lead to human health problems.

Concentration of mercury within the vicinity of mines and processing units ranged from $1.7 \pm 0.49 \mathrm{mg} / \mathrm{kg}$ to $53.8 \pm 13.27$ $\mathrm{mg} / \mathrm{kg} \mathrm{dw}$ (Table 2). The processing unit at Londoni amalgamation centre was constructed indoor while that of Sambaru was constructed outdoor. In outdoor ponds, tailings were deposited above unlined surface and exposed to the environment. High concentration of mercury at immediate vicinity of outdoor than indoor units might be due to transportation of tailings rich in mercury by wind or through leaching especially during rainy season compared to the indoor units where tailings rich in mercury are safe stored. Fig. 4 shows variations of mercury concentrations in soils around outdoor and indoor amalgamation units. The results indicate that soils taken at the immediate vicinity of processing units are contaminated by mercury at higher level than the Tanzania maximum limits of mercury contaminants in soils which is $2 \mathrm{mg} / \mathrm{kg}[18]$. 
Table 2. Mean concentrations ( $\pm S D)$ of some heavy metals in soils of the study area.

\begin{tabular}{|c|c|c|c|c|c|}
\hline \multirow{2}{*}{ Site } & \multirow{2}{*}{ Depth(cm) } & \multicolumn{4}{|c|}{ Metal concentration $(\mathrm{mg} / \mathrm{kg} \mathrm{dw}),(\mathrm{n}=2), 95 \% \mathrm{CL}$} \\
\hline & & $\mathbf{H g}$ & $\mathbf{P b}$ & $\mathbf{Z n}$ & $\mathbf{C u}$ \\
\hline \multirow{2}{*}{ S1 } & $0-15$ & $20.06 \pm 3.41$ & $14.76 \pm 3.14$ & $0.68 \pm 0.19$ & $8.39 \pm 2.12$ \\
\hline & $15-30$ & $18.83 \pm 2.77$ & $12.86 \pm 0.96$ & $0.42 \pm 0.06$ & $10.65 \pm 1.12$ \\
\hline \multirow{2}{*}{ S2 } & $0-15$ & $7.77 \pm 0.89$ & $16.08 \pm 2.94$ & $2.24 \pm 0.06$ & $10.99 \pm 0.13$ \\
\hline & $15-30$ & $5.71 \pm 1.55$ & $11.96 \pm 0.62$ & $1.74 \pm 0.23$ & $9.07 \pm 2.18$ \\
\hline \multirow{2}{*}{ S3 } & $0-15$ & $2.26 \pm 0.16$ & $11.46 \pm 0.16$ & $1.89 \pm 0.08$ & $3.42 \pm 1.44$ \\
\hline & $15-30$ & $1.78 \pm 0.22$ & $8.70 \pm 2.78$ & $1.70 \pm 0.51$ & $3.19 \pm 0.20$ \\
\hline \multirow{2}{*}{ S4 } & $0-15$ & $50.92 \pm 4.84$ & $9.87 \pm 1.38$ & $1.08 \pm 0.24$ & $12.02 \pm 1.72$ \\
\hline & $15-30$ & $53.8 \pm 13.27$ & $10.01 \pm 0.70$ & $1.13 \pm 0.52$ & $8.502 \pm 0.24$ \\
\hline \multirow{2}{*}{ S5 } & $0-15$ & $6.69 \pm 1.04$ & $12.6 \pm 0.32$ & $0.91 \pm 0.24$ & $10.25 \pm 1.76$ \\
\hline & $15-30$ & $6.35 \pm 0.11$ & $12.26 \pm 0.80$ & $1.09 \pm 0.43$ & $9.07 \pm 0.34$ \\
\hline \multirow{2}{*}{ S6 } & $0-15$ & $3.68 \pm 0.21$ & $10.24 \pm 2.20$ & $0.94 \pm 0.34$ & $8.80 \pm 0.28$ \\
\hline & $15-30$ & $2.83 \pm 0.50$ & $10.45 \pm 4.95$ & $1.18 \pm 0.55$ & $9.96 \pm 0.69$ \\
\hline \multirow{2}{*}{ S7 } & $0-15$ & $4.68 \pm 0.69$ & $15.72 \pm 3.44$ & $1.19 \pm 0.38$ & $15.71 \pm 0.61$ \\
\hline & $15-30$ & $5.84 \pm 0.88$ & $11.13 \pm 6.84$ & $1.27 \pm 0.26$ & $18.72 \pm 1.45$ \\
\hline \multirow{2}{*}{ S8 } & $0-15$ & $5.10 \pm 0.32$ & $22.24 \pm 0.07$ & $2.61 \pm 0.13$ & $15.37 \pm 6.19$ \\
\hline & $15-30$ & $3.94 \pm 0.31$ & $21.98 \pm 1.13$ & $2.45 \pm 0.34$ & $15.19 \pm 1.95$ \\
\hline \multirow{2}{*}{ S9 } & $0-15$ & $4.68 \pm 1.59$ & $13.81 \pm 3.37$ & $1.22 \pm 0.15$ & $14.14 \pm 2.21$ \\
\hline & $15-30$ & $2.59 \pm 0.24$ & $13.35 \pm 2.17$ & $1.19 \pm 0.29$ & $29.42 \pm 6.15$ \\
\hline \multirow{2}{*}{ S10 } & $0-15$ & $5.33 \pm 0.10$ & $17.28 \pm 0.65$ & $1.25 \pm 0.34$ & $22.75 \pm 3.24$ \\
\hline & $15-30$ & $3.14 \pm 1.02$ & $19.01 \pm 0.98$ & $1.16 \pm 0.19$ & $16.58 \pm 4.41$ \\
\hline \multirow{2}{*}{ S11 } & $0-15$ & $1.7 \pm 0.49$ & $13.59 \pm 0.36$ & $0.71 \pm 0.19$ & $13.43 \pm 2.69$ \\
\hline & $15-30$ & $1.73 \pm 0.18$ & $13.23 \pm 1.28$ & $1.78 \pm 0.13$ & $11.68 \pm 0.45$ \\
\hline \multirow{2}{*}{$\mathrm{S} 12$} & $0-15$ & $4.53 \pm 0.69$ & $9.18 \pm 0.39$ & $1.09 \pm 0.22$ & $11.09 \pm 1.99$ \\
\hline & $15-30$ & $3.94 \pm 1.01$ & $9.49 \pm 0.36$ & $0.73 \pm 0.31$ & $9.05 \pm 0.10$ \\
\hline \multirow{2}{*}{ S13 } & $0-15$ & $2.56 \pm 0.14$ & $14.42 \pm 1.63$ & $0.98 \pm 0.12$ & $10.68 \pm 1.03$ \\
\hline & $15-30$ & $2.00 \pm 0.35$ & $14.26 \pm 1.81$ & $1.14 \pm 0.25$ & $12.3 \pm 1.33$ \\
\hline S14 & $0-15$ & $53.54 \pm 4.41$ & $15.76 \pm 0.79$ & $1.37 \pm 0.43$ & $23.72 \pm 0.79$ \\
\hline S15 & $0-15$ & $4.46 \pm 2.13$ & $13.63 \pm 0.51$ & $1.00 \pm 0.38$ & $17.92 \pm 2.29$ \\
\hline
\end{tabular}
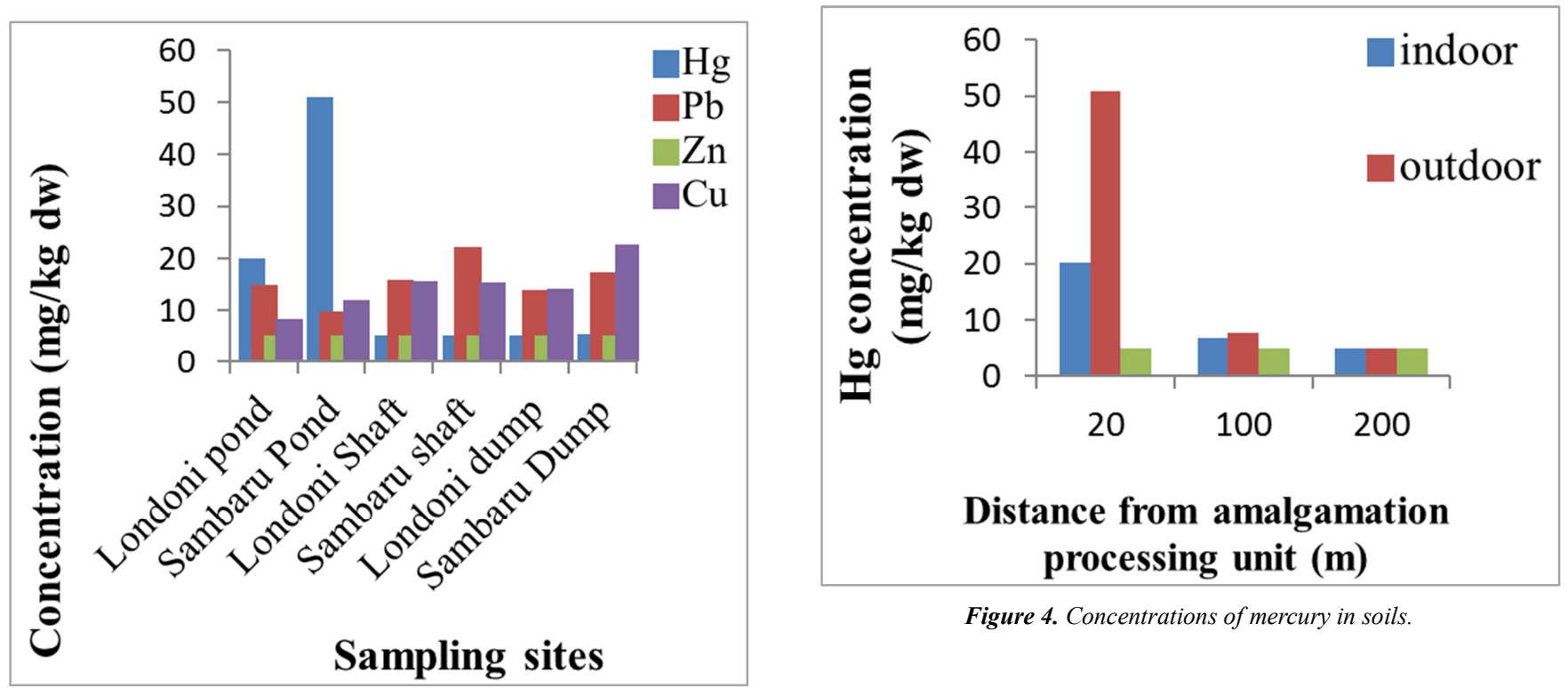

Figure 4. Concentrations of mercury in soils.

Figure 3. Levels of heavy metals in soils around small scale mines. 


\subsection{Heavy Metals Concentrations in Surface and Groundwater}

Table 3 shows concentration of heavy metals in water at the study area. Results indicate that concentrations of mercury at Londoni borehole (SP3) and dug well (SP4) were below the instrumental detection limits of $0.01 \mathrm{mg} / \mathrm{L}$. These wells were located upstream to Londoni processing centre, therefore might not be affected by either overflow from amalgamation ponds or drainage from tailings deposited at Londoni processing centre. Concentration of mercury in water from active shaft (SP1) and abandoned shaft (SP2) both from mine at Londoni is related to illegal panning by mercury which takes place in mining areas or seasonal streams during rainy season. Due to water problems in Londoni and Sambaru, miners and communities are using water from abandoned shaft for domestic purposes including drinking, although concentration of mercury in this shaft is above the Tanzania maximum limit for drinking water of $0.001 \mathrm{mg} / \mathrm{L}$ [18]. Mercury contamination in drinking water is reported to cause developmental disabilities as it affects brain, liver, kidney and central nervous system. The mercury problem in Mina Mata Bay, Japan that caused birth to infants with severe developmental disabilities is one of the most severe reported effects of mercury [19].

Concentration of lead was below the Tanzanian maximum limit for drinking water of $0.1 \mathrm{mg} / \mathrm{L}$ at both active shaft (SP1) and abandoned shaft (SP2), but it was higher than the WHO recommended guideline concentration of $0.05 \mathrm{mg} / \mathrm{L}$ at active shaft (SP1). Even the lowest doses of lead can impair the nervous system and affect foetus, infants and children, resulting in lowering the intelligence quotient (IQ).

Concentrations of zinc in all water samples were below the instrumental detection limit of $0.01 \mathrm{mg} / \mathrm{L}$, while that of copper were within the Tanzanian maximum limit for drinking water of $3 \mathrm{mg} / \mathrm{L}$ [18]. These metals are among the important trace elements that play a vital role in the physiological and metabolic process of many organisms. Higher or lower concentrations in organisms are undesirable and can cause health problems [20]. For instance severe deficiency of copper can cause demineralization of bones, demyelimination of neural tissue, anemia, fragility of arteries, myocardial fibrosis, graying of hair [20].

Table 3. Mean concentrations ( $\pm S D$ ) of metals in water samples within vicinity of mines and processing units.

\begin{tabular}{lllll}
\hline \multirow{2}{*}{ Site } & \multicolumn{4}{l}{ Mean $\pm \mathbf{S D},(\mathbf{n}=\mathbf{3}), \mathbf{9 5 \%} \mathbf{C L}$} \\
\cline { 2 - 5 } & $\mathbf{H g}$ & $\mathbf{P b}$ & $\mathbf{Z n}$ & $\mathbf{C u}$ \\
\hline SP1 & $0.028 \pm 0.01$ & $0.086 \pm 0.01$ & bdl & $0.163 \pm 0.07$ \\
SP2 & $0.013 \pm 0.01$ & $0.039 \pm 0.01$ & bdl & $0.092 \pm 0.01$ \\
SP3 & bdl & $0.024 \pm 0.001$ & bdl & $0.124 \pm 0.03$ \\
SP4 & bdl & bdl & bdl & $0.079 \pm 0.01$ \\
SP5 & $0.061 \pm 0.01$ & $0.026 \pm 0.01$ & bdl & bdl \\
SP6 & $0.046 \pm 0.02$ & $0.099 \pm 0.01$ & bdl & $0.17 \pm 0.04$ \\
\hline
\end{tabular}

bdl-below instrumental detection limit $0.01 \mathrm{mg} / \mathrm{l}$

Fig. 5 shows variations of heavy metals in water samples collected around mining areas. With exception to water collected from stagnant water Londoni, in other locations the abundance of the metals in individual site were in the order of $\mathrm{Cu}>\mathrm{Pb}>\mathrm{Hg}$. This suggests that rocks and mining wastes are rich in copper and lead, while the mercury originates from amalgamation units.

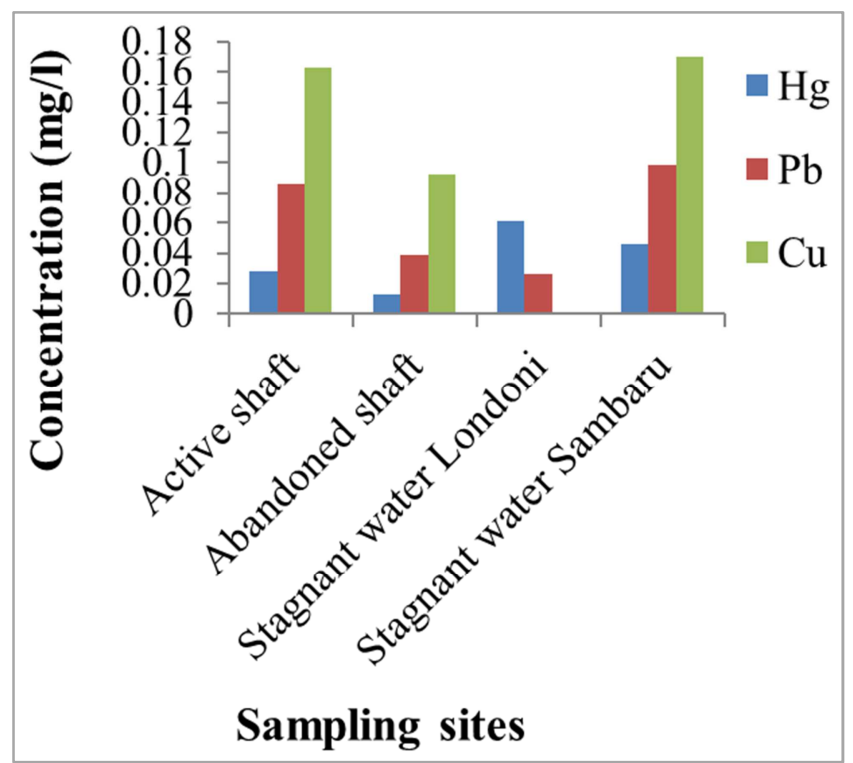

Figure 5. Levels of heavy metals in water bodies around small scale mines.

\section{Conclusion}

The results of this study revealed that water and soils in the studied areas around the small scale mines of Londoni and Sambaru are contaminated with heavy metals. The concentrations of contaminants in most of the sites were considerable within the recommended national and international limits for drinking water, and soil for habitat and agriculture. The amalgamation and burning activities, improper waste rocks and tailings disposal, discharge of mine water to the surroundings and leachates from waste rocks and tailings appears to be the major source of the heavy metals in water and soils of the area. Immediate adverse effect may not be feasible but continuing contamination may lead to serious human health and environmental problems. The problems identified under this study therefore indicate necessity to initiate actions to remediate soil and water in the area as well as to control further contamination.

\section{Acknowledgements}

The authors wish to express special thanks to Prof. R. Kiunsi of Ardhi University, Tanzania for the insight that leads to conducting this study. Mr. G. Senge, inspector of mines and explosives at Central Zone mine office is acknowledged for his constructive ideas that were useful during field campaigns. Mr. A. Ndimbo and Mr. R. Mbulume, laboratory technicians at Ardhi University, for their assistance throughout the field and laboratory works. 


\section{References}

[1] Jerie S. and Sibanda E. The environmental effects on effluents disposal at gold mines in Zimbabwe. A case study of Tiger reef mine in Kwekwe. J. Sustainable development in Africa, 2010, 12: 51-69.

[2] Akabzaa T. Boom and dislocation. The environmental and social impacts of mining in the Wassa West District of Ghana.Accra, Third World Network Africa, 2000.

[3] Ajusa, J. A review of refractory ore processes, A and B metallurgical consultants, Kwekwe, Zimbabwe, 2003.

[4] Hentschel, T., Hruschka, F. and Priester, M. Artisanal and small scale mining. Challenges and Opportunities, 2003.

[5] Diaz, E. Mercury pollution at gold mining sites in the Amazon environment. Principle of environmental toxicology, University of Idaho, 2000.

[6] Idowu O. S., Adelakun, K. M., Osaguona P and Ajayi J. Mercury contamination in artisanal gold mining area of Manyera river, Niger state Nigeria. Journal of Environmental Research and Management, 2013, 4(9): 326-333.

[7] Adler, R and Rascher, J. A strategy for the management of acid mine drainage from gold mines in Gauteng. Report. No.CSIR/NRE/PW/ER/2007/0053/C.CSIR, Pretoria, 2007.

[8] Gunson, A.J., Thompson, M., Baker, R., Veiga, M., Spiegel, S and Cannon, M. Environmental and Health Assessment Report: Removal of Barriers to the Introduction of Cleaner: Artisanal Gold Mining and Extraction Technologies. Vienna: United Nations Industrial Development Organization, 2006.

[9] Appleton, J. D., Taylor, H., Lister, T. R., Smith, B., Drasch G and Reilly S. Final report for an assessment of the environment and health in the Rwamagaza area, Tanzania. UNIDO Project EG/GLO/01/G34. British geological survey, 2014.
[10] Bitala, M., Kweyunga C and Makono, M. Levels of heavy metals and cyanide in soil, sediment and water from the vicinity of North Mara Gold Mine in Tarime District, Tanzania, 2009.

[11] Telmer, F. Trends in Gold Mining in the Developing World. Challenges and Outcomes Quito, Ecuador, 2006.

[12] Adams, V. D. Water and Wastewater examination manual, Lewis Publishers Inc, USA, 1991.

[13] Carter, M. R and Gregorich, E. G. Soil sampling and methods of analysis. Canadian Society of soil Science, Tailor \& Francis Group, LLC, 2008.

[14] Mwegoha, W.J. and Kihampa C. Heavy metal contamination in agricultural soils and water in Dar es Salaam city, Tanzania: African Journal of Environmental Science and Technology, 2010, 4(11): 763-769.

[15] Mico, C., Peris, M., Recatala, L and Sanchez, J. Baseline valued for heavy metal in agricultural soils in European Mediterranean region. Sci. Total Environ, 2007, 378: 13-17.

[16] Machiwa, J. Heavy metal levels in paddy soils and rice (ORYZA SATIVA (L)) from wetlands of Lake Victoria basin, Tanzania. Tanz. J. Sci, 2010, 36(2010).

[17] Ina S., Iryna, K., Marie, H., Claudia, L., Frauke, W and Ingo K. How healthy is urban horticulture in high traffic areas? Trace metal concentrations in vegetable crops from plantings within inner city neighbourhoods in Berlin, Germany. Journal of Environmental Pollution, Elsevier, 2012, 165: 124-132.

[18] Tanzania Standards for Receiving Water, Effluents and soils (TZS 789:2003). Tanzania Bureau of Standards.

[19] Mami, A and Mark J. H. Minamata as Negative Heritage: Implications for Fukushima, 2013.

[20] Dara, S. A Text book of Environmental chemistry and Pollution. S. Chand and Company Ltd., New Delhi, 2009. 